\title{
A triazatruxene-based molecular dyad for single-component organic solar cells
}

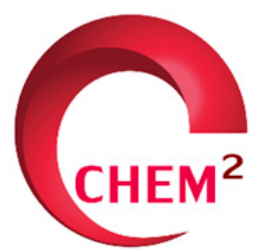

Antoine Labrunie a, Giacomo Londi b, Sergey V. Dayneko c, Martin Blais a, Sylvie Dabos-Seignon a, Gregory C. Welch c, David Beljonne b, Philippe Blanchard a,*, Clément Cabanetos a,*

Email(s): philippe.blanchard@univ-angers.fr; clement.cabanetos@univ-angers.fr

a CNRS UMR 6200, MOLTECH-Anjou, University of Angers, 2 Bd Lavoisier, 49045 Angers, France

b Chimie des Matériaux Nouveaux \& Centre d'Innovation et de Recherche en Matériaux Polymères, Université de Mons - UMONS / Materia Nova, Place du Parc, 20, B-7000 MONS

c Department of Chemistry, University of Calgary, 2500 University Drive N.W., Calgary, Alberta T2N 1N4, Canada

\begin{abstract}
The synthesis, characterization and use of a new donor-acceptor molecular dyad in single component organic solar cells are reported. The dyad, composed of a triazatruxene-based push-pull 'donor' unit linked to a $\mathrm{C}_{60}$ 'acceptor' unit through a non-conjugated $\sigma$ connector, led to promising power conversion efficiencies of $0.6 \%$ when embedded in simple devices exhibiting the architecture: indium tin oxide (ITO)/poly(3,4-ethylenedioxythiophene): polystyrene sulfonic acid (PEDOT:PSS)/dyad/Al.
\end{abstract}

Keywords: Single component organic solar cells, triazatruxene, dyad, fullerene, organic synthesis, click chemistry.

\section{Introduction}

With power conversion efficiency (PCE) now exceeding 15\% for tandem architectures [1, 2] and 13\% for single layers [3], organic photovoltaics (OPV) continues to demonstrate their potential as a viable renewable energy conversion technology [4]. To reach such high efficiencies, efforts have been devoted to controlling the nano-morphology of the bulk heterojunction active layer, usually composed of an electron donor (D) blended with an electron acceptor (A), via chemical and device-processing engineering [5-7]. Hence, to improve free charge-carrier generation and transport, several empirical parameters such as the donor/acceptor $(\mathrm{D} / \mathrm{A})$ ratio, the nature of the processing solvent, different annealing conditions, and/or the use of additives are routinely assessed and adjusted [8, 9]. However, even if the optimized morphology is luckily achieved, the latter usually evolves leading, in general, to a drastic decrease in the device performance.

In this context, the concept of single-component organic solar cells (SCOSCs) was introduced in the late 90 's in which the active layer is solely based on an "all-in-one" molecule built by connecting the donor and the acceptor through a covalent linkage [10,11]. Designed to ensure efficient charge separation, simplified device fabrication and a stable phase segregation, such molecular architectures are generally and unfortunately impeded by high carrier recombination and low photocurrent in solar cells [12]. Consequently, with PCEs lagging behind those of blend devices, such approach has clearly been dismissed by the organic photovoltaic community. However, trends observed from scarce examples dealing with molecular system based on SCOSCs indicate a significant and gradual improvement in efficiencies, from less than $0.5 \%$ to more than $2.4 \%$, as a result of a better understanding of the structureproperties-function relationships [13-17]. 
Motivated by this challenging topic, we have recently reported the synthesis and characterization of a donor- $\sigma$-acceptor molecular dyad, consisting of a triphenylamine-based push-pull $\pi$-conjugated system linked to a fullerene $\left(\mathrm{C}_{60}\right)$ through a non-conjugated $\sigma$ linker (TPA- $\sigma-\mathbf{C}_{60}$, Figure 1) [18]. Beyond a modest efficiency $(0.4 \%)$, we have demonstrated that such a simple architecture can lead to charge percolations within the active layer and, above all, that the simple synthetic strategy/methodology implemented in this study can be easily extended to other building blocks with different electrochemical and optical properties.
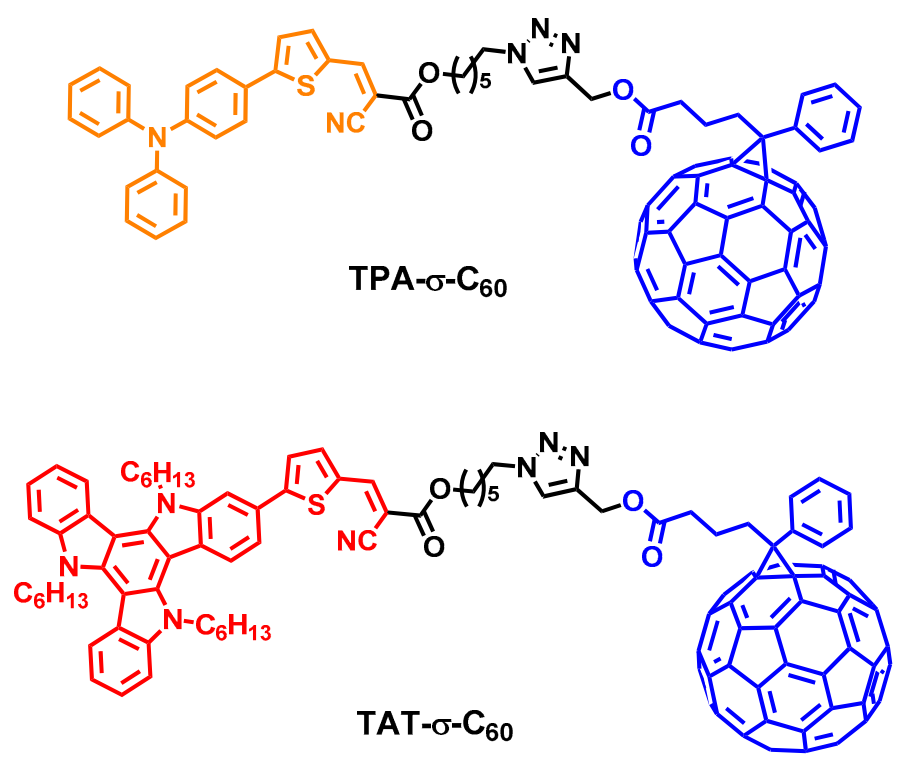

Figure 1. Illustration of the molecular dyads TPA- $\sigma-\mathbf{C}_{60}$ and TAT- $\sigma-\mathbf{C}_{60}$

To improve the photovoltaic efficiencies, the effect of substituting the triphenylamine electron-rich block by a triazatruxene moiety is evaluated herein (TAT- $\sigma-\mathbf{C}_{60}$, Figure $\left.\mathbf{1}\right)$. Indeed, though barely used in OPV [19-21], mainly as end-capping moiety, triazatruxene has already shown unique properties owing to a perfectly flat and symmetrical $\pi$-conjugated core and tunable solubility through easy modulation of the side chains on the indole units.

\section{Results and Discussion}

The synthetic protocol for the preparation of the molecular dyad TAT- $\boldsymbol{\sigma}-\mathbf{C}_{60}$ is depicted in Scheme 1.

The N-hexyl substituted triazatruxene TAT, synthesized according to reported procedures [19], was first brominated in the presence of $\mathrm{N}$-bromosuccinimide, and the thiophene unit was incorporated via reaction with tributyl(thiophen-2-yl)stannane under Stille pallado-catalyzed conditions. The resulting compound (TAT-T) was functionalized with a formyl moiety, which was subjected to a Knoevenagel condensation with the $\mathrm{CH}_{2}$-activated 6-azidohexyl-2-cyanoacetate, affording the azido-functionalized push-pull molecule TAT- $\sigma-\mathbf{N}_{3}$. Reaction of TAT- $\sigma-\mathbf{N}_{3}$ with the [6,6]-phenyl- $\mathrm{C}_{61}$ butyric acid propargyl ester $\mathbf{C}_{60}-\mathbf{A}$ via a copper-catalyzed 1,3-dipolar Huisgen cyclo-addition finally, led to the target TAT- $\sigma-\mathbf{C}_{60}$ dyad.

The optical signature of the dyad, recorded in diluted dichloromethane solutions, corresponds to the superimposition of both constituents, namely the TAT- $\boldsymbol{\sigma}-\mathbf{N}_{3}$ and the fullerene derivative $\mathbf{C}_{60}-\mathbf{A}$, confirming the weak electronic coupling between these two entities in the ground state (Figure 2).

According to time-dependent density-functional theory (TD-DFT) calculations (see Supporting Information), the broad band centered around $500 \mathrm{~nm}$ can be attributed to an internal charge transfer (ICT) from the electron-rich triazatruxene moiety to the electron-withdrawing cyanoacrylate group, thus highlighting the strong push-pull behavior of the donor part of the dyad (Figure 3). 


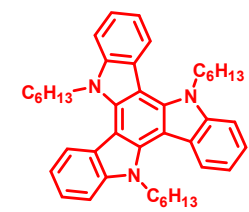

TAT

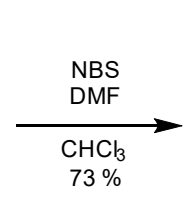

$\%$

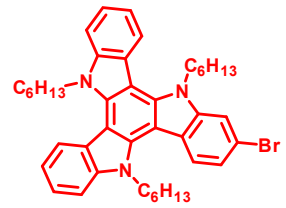

TAT-Br
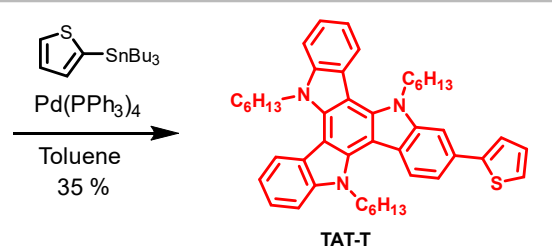

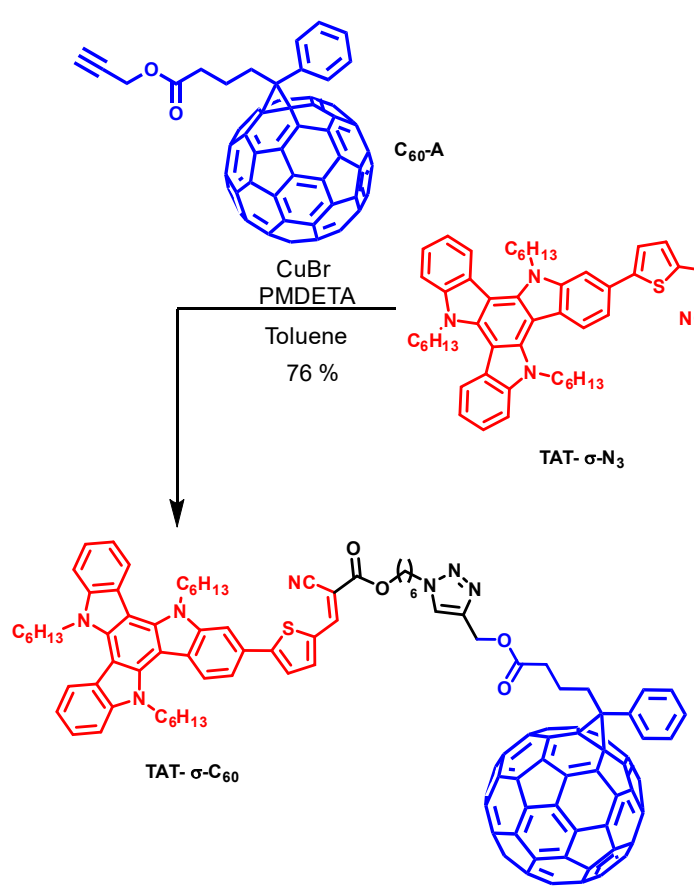

Scheme 1. Synthesis of the molecular dyad TAT- $\sigma-\mathbf{C}_{60}$

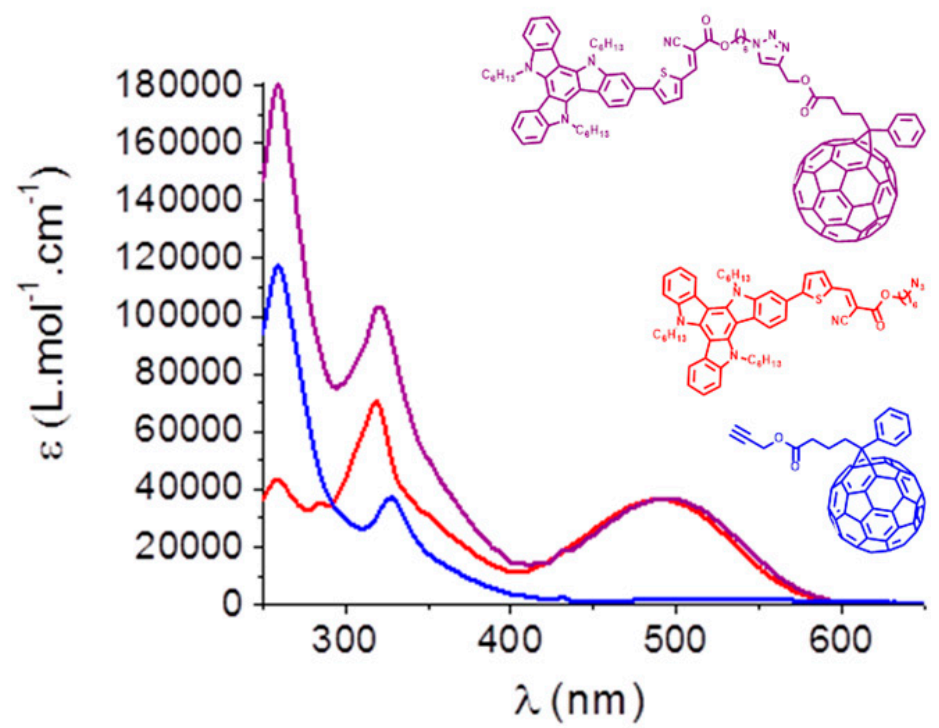

Figure 2. UV-Vis absorption spectra of $\mathbf{T A T}-\boldsymbol{\sigma}-\mathbf{C}_{\mathbf{6}}$ (purple), $\mathbf{T A T}-\boldsymbol{\sigma}-\mathbf{N}_{3}$ (red), and $\mathbf{C}_{60}-\mathbf{A}$ (blue) recorded in diluted $\mathrm{CH}_{2} \mathrm{Cl}_{2}$ solutions $\left(c a 1 \times 10^{-5} \mathrm{M}\right)$. 


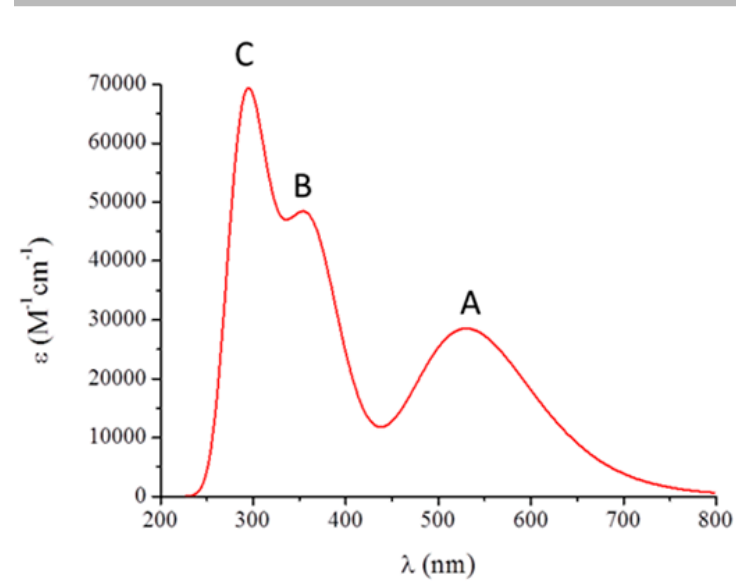

A:
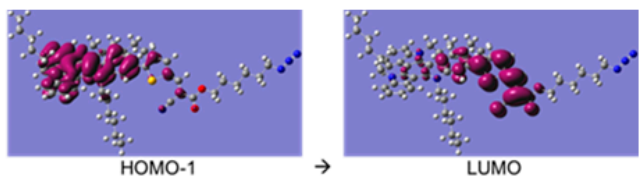

B:
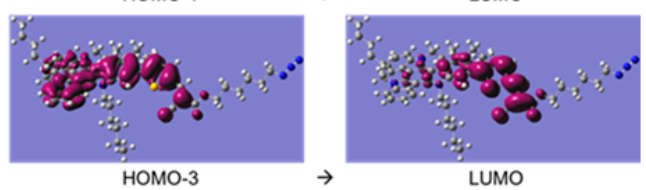

C:

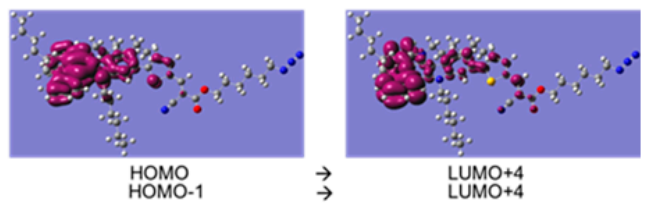

Figure 3. Theoretical simulated spectrrum of TAT- $\sigma-\mathbf{N}_{3}$ in dichloromethane (left) and corresponding electronic transitions (right).

The cyclic voltammogram of the dyad TAT- $\sigma-\mathbf{C}_{60}$, performed in dichloromethane with $\mathrm{Bu}_{4} \mathrm{NPF}_{6}$ as the supporting electrolyte and exhibiting reversible oxidation and reduction waves, corresponds to the superimposition of both the donor and the acceptor moieties contributions (Figure 4).
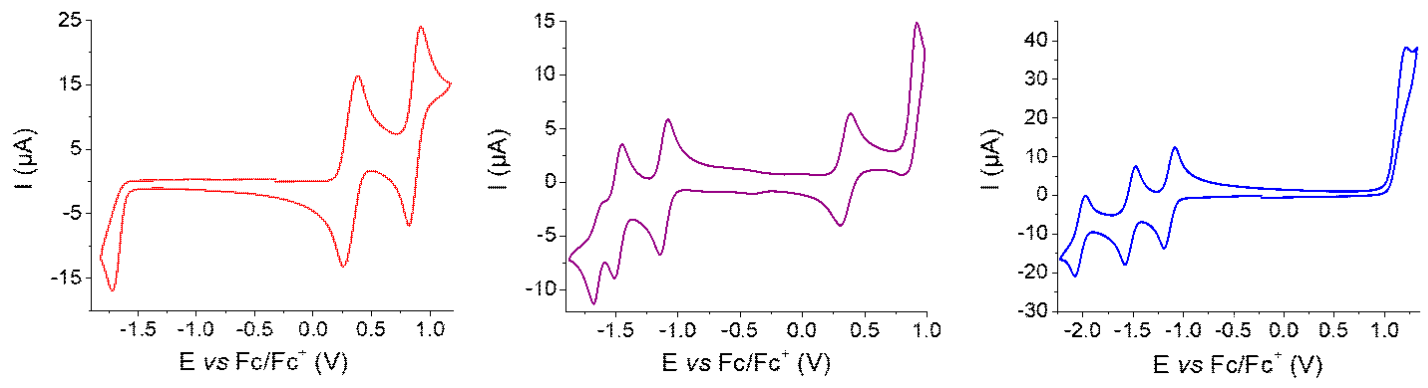

Figure 4. Cyclic voltammograms of TAT- $\sigma-\mathbf{N}_{3}$ (red), TAT- $\sigma-\mathbf{C}_{60}$ (purple), and the $\mathbf{P C} \mathbf{C}_{61} \mathbf{B M}$ as a reference fullerene (blue) in $0.1 \mathrm{M} \mathrm{Bu}_{4} \mathrm{NPF}_{6} / \mathrm{CH}_{2} \mathrm{Cl}_{2}$, scan rate $100 \mathrm{mV} \mathrm{s}{ }^{-1}$, Pt working and counter electrode.

In accordance with the electrochemical signature of $\mathbf{T A T}-\boldsymbol{\sigma}-\mathbf{N}_{3}$, a first reversible one-electron oxidation wave, assigned to the formation of the stable radical cation of the triazatruxene push-pull block, was recorded for $\mathbf{T A T}-\boldsymbol{\sigma}-\mathbf{C}_{\mathbf{6 0}}$. In the negative region, the two first successive reversible reduction waves can be attributed to the step-by-step, one-electron reduction of the fullerene moiety, as deduced from the cyclic voltammogram of $\mathbf{P C}_{61} \mathbf{B M}$. Finally, the third irreversible reduction process corresponds to the formation of a radical-anion on the push-pull system, once again in agreement with the pattern recorded for TAT- $\sigma-\mathbf{N}_{3}$ (Table 1 and S10).

Table 1. Electrochemical data. V vs Fc+/Fc. *irreversible process. a) $\mathrm{E}_{\mathrm{HOMO}}(\mathrm{eV})=-\left(\mathrm{Onset}_{\mathrm{ox}}+5.1\right)$, $\mathrm{E}_{\text {LuMO }}(\mathrm{eV})=-\left(\right.$ Onset $\left._{\text {red }}+5.1\right)[22]$.

\begin{tabular}{|c|c|c|c|c|c|c|c|}
\hline Compound & $\begin{array}{l}E_{p^{1}}{ }^{2} \\
(V)\end{array}$ & $\begin{array}{l}\mathbf{E}_{\mathrm{pc}^{2}} \\
(\mathrm{~V})\end{array}$ & $\begin{array}{l}E_{p_{c}^{3}} \\
(V)\end{array}$ & $\begin{array}{l}\mathrm{E}_{\mathrm{pa}}{ }^{1} \\
(\mathrm{~V})\end{array}$ & $\begin{array}{l}\mathrm{E}_{\mathrm{pa}}^{2} \\
\text { (V) }\end{array}$ & $\begin{array}{c}\text { HOMO } \\
(e V)^{a)}\end{array}$ & $\begin{array}{c}\text { LUMO } \\
(\mathrm{eV})^{\mathrm{a})}\end{array}$ \\
\hline $\mathrm{PC}_{61} \mathrm{BM}$ & -1.17 & -1.56 & -2.06 & $1.21 *$ & - & -6.15 & -4.02 \\
\hline TAT- $\sigma-\mathbf{N}$ & $-1.71 *$ & - & - & 0.41 & 0.92 & -5.33 & -3.49 \\
\hline TAT- $\sigma-\mathrm{C}_{60}$ & -1.15 & -1.51 & $-1.68^{*}$ & 0.38 & 0.92 & -5.37 & -4.05 \\
\hline
\end{tabular}


Frontier molecular orbitals, either simulated by quantum chemistry (see Supporting Information) or estimated from the onset potentials of the oxidation and reduction processes, show favorable matching between the donor $\left(\mathbf{T A T}-\boldsymbol{\sigma}-\mathbf{N}_{3}\right.$ ) and the fullerene-based acceptor, a prerequisite for an efficient photo induced electron transfer (Figure 4 and Table 1).

To evaluate the utility of the dyad as single photoactive material for organic solar cells, devices with an architecture indium tin oxide (ITO)/poly(3,4-ethylenedioxythiophene): polystyrene sulfonic acid (PEDOT:PSS)/TAT- $\boldsymbol{\sigma}-\mathbf{C}_{60} / \mathrm{Al}$ were fabricated and tested. Owing to its good solubility, different processing solvents, namely 2-methyltetrahydrofuran (Me'THF), chlorobenzene (CB) and chloroform (CF) were used to solubilize TAT- $\sigma-\mathbf{C}_{60}$. It turns out that in the same conditions of concentration and deposition spin-speed, i.e., $10 \mathrm{mg} \mathrm{mL}-1$ and $4000 \mathrm{rpm}$ respectively, the best quality films, and therefore best efficiencies, were obtained from chloroform solutions (Table S1). Power conversion efficiencies of ca $0.41 \%, 0.22 \%$ and $0.01 \%$ were indeed obtained when the dyad is processed with $\mathrm{CF}$, the $\mathrm{CB}$ and the Me'THF respectively.

To gain further insights, the corresponding nano-scale morphologies were investigated by atomic-force microscopy (AFM). As shown in Figure 5, both chloroform (CF) and chlorobenzene (CB) processed active layers showing small and homogenous nanodomains. However, with CB, a broad number of large size defects (white spots) are noticed, which are detrimental to the device performance. On the other hand, the surface topography of the active layer spun cast from the MeTHF solution reveals a quite different organization with villi-like microscopic patterns characterized by a roughness of $c a 21 \mathrm{~nm} v s .0 .7$ $\mathrm{nm}$ for the other two films (not taking into account the large defects, see Supporting Information).

CF

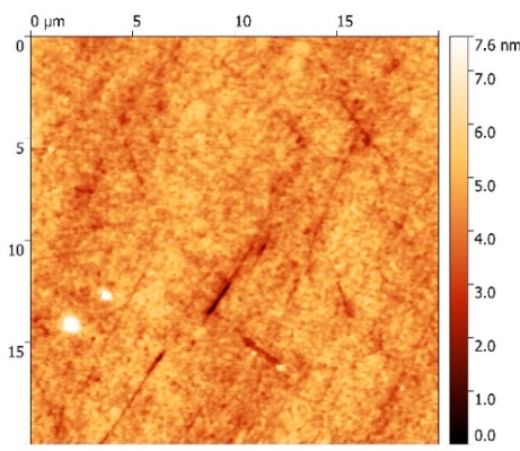

CB

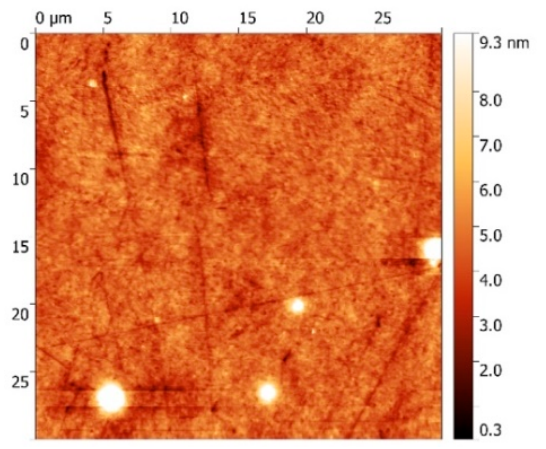

Me'THF

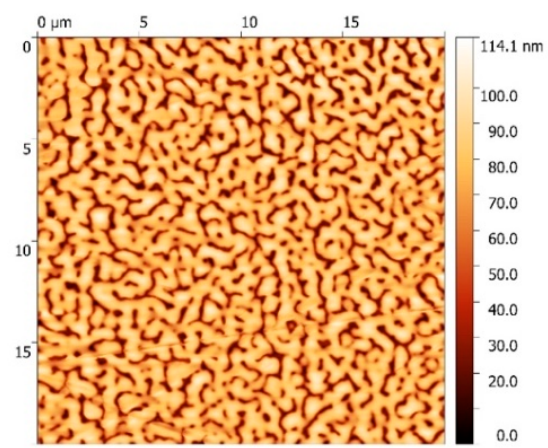

Figure 5. Surface topography images of the different active layers probed by atomic-force microscopy.

To optimize the efficiencies, the thickness dependence of the chloroform-processed active layer was then investigated, revealing an optimum around $80 \mathrm{~nm}$ associated to a maximum PCE of $c a 0.56 \%$ (Table 2).

Table 2. Photovoltaic data obtained with active layers of different thicknesses

\begin{tabular}{ccccc}
\hline $\begin{array}{c}\text { Thickness } \\
(\mathbf{n m})\end{array}$ & $\begin{array}{c}\text { Voc } \\
\mathbf{( V )}\end{array}$ & $\begin{array}{c}\text { Jsc } \\
\left(\mathbf{m A} \cdot \mathbf{c m}^{-\mathbf{1}}\right)\end{array}$ & $\begin{array}{c}\text { FF } \\
\mathbf{( \% )}\end{array}$ & $\begin{array}{c}\text { PCE } \\
\mathbf{( \% )}\end{array}$ \\
\hline 50 & 0.87 & 1.70 & 31.3 & 0.47 \\
80 & 0.89 & 2.05 & 30.7 & 0.56 \\
95 & 0.88 & 1.96 & 28.6 & 0.49 \\
110 & 0.88 & 1.57 & 26.7 & 0.37 \\
120 & 0.87 & 1.57 & 27.0 & 0.37 \\
\hline
\end{tabular}

The corresponding current density-voltage $(\mathrm{J}-\mathrm{V})$ characteristic and the external quantum-efficiency (EQE) spectrum, performed under monochromatic irradiation, are plotted in Figure 6. 

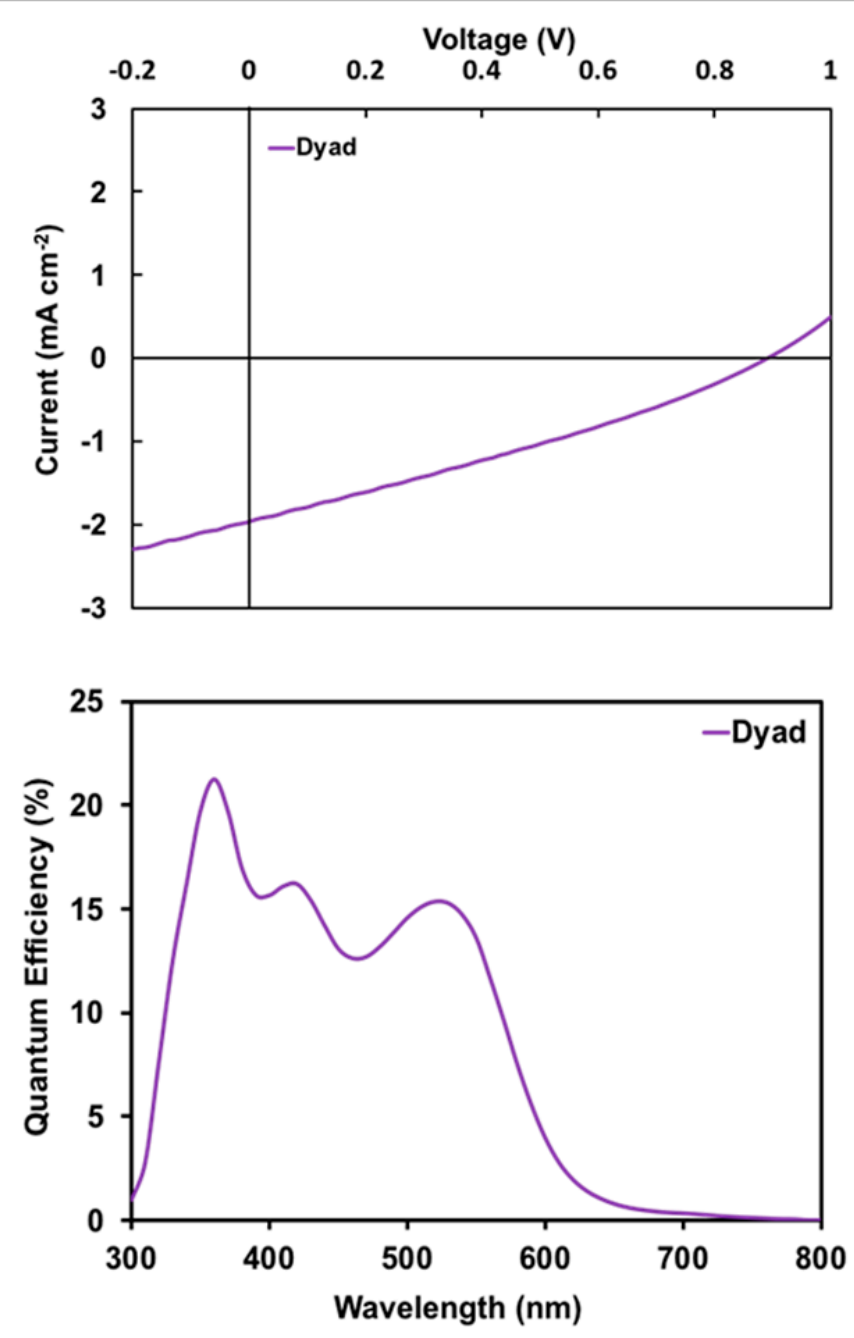

Figure 6. Top: J-V characteristics measured under AM 1.5 simulated solar light illumination (100 $\mathrm{mW} \cdot \mathrm{cm}^{-2}$ ) and bottom: external-quantum efficiency spectrum of the best SCOSC based on TAT- $\sigma-\mathbf{C}_{\mathbf{6 0}}$.

In agreement with the UV-Vis experiments, the two bands at $520 \mathrm{~nm}$ and $420 \mathrm{~nm}$ can be attributed to the contribution of the TAT-based push-pull donor, while the third one, found at $360 \mathrm{~nm}$, corresponds to the photon-to-current conversion of the fullerene derivative.

\section{Conclusions}

The synthesis of an original donor-acceptor molecular dyad and its use as electroactive material for single-component organic solar cells are demonstrated herein. Power conversion efficiencies of $c a 0.6 \%$ were indeed measured in basic and simple devices. In addition, it is noteworthy that active layers thicker than a hundred nanometers still generate a photo-current. Although modest and still far from those of well performing bulk heterojunction blend devices, these promising results highlight the potential of such triazatruxene-based dyad to convert light into electricity, and hopefully, will contribute to a continuing surge of interest in this understudied area, namely the single-component organic photovoltaics. 


\section{Additional Information}

Supporting information is available online. Correspondence and requests for materials should be addressed to the corresponding author.

\section{Materials and Methods}

\section{General}

Ground-state DFT geometry optimizations and TD-DFT single-point calculations were carried out using GAUSSIAN 16 [23] suite package. 6-31G** basis sets were chosen for all the atomic species. The optimally-tuned $\omega$ B97X-D [24] exchange-correlation energy functional was used throughout the simulations. In order to take into account solvation effects in the reproduction of the absorption spectra, solvent dichloromethane molecules were treated as a polarizable continuum (PCM).

All reagents and chemicals from commercial sources were used without further purification. Solvents were dried and purified using standard techniques. Column chromatography was performed with analytical-grade solvents using Aldrich silica gel (technical grade, pore size $60 \AA, 230-400$ mesh particle size). Flexible plates ALUGRAM® Xtra SIL G UV254 from MACHEREY-NAGEL were used for TLC. Compounds were detected by UV irradiation (Bioblock Scientific) or staining with iodine, unless otherwise stated. NMR spectra were recorded with a Bruker AVANCE III $300\left({ }^{1} \mathrm{H}, 300 \mathrm{MHz}\right.$ and ${ }^{13} \mathrm{C}$, $75 \mathrm{MHz})$ and a Bruker AVANCE DRX $500\left({ }^{1} \mathrm{H}, 500 \mathrm{MHz}\right.$ and $\left.{ }^{13} \mathrm{C}, 125 \mathrm{MHz}\right)$. Chemical shifts are given in ppm relative to tetramethylsilane (TMS) and the coupling constants J in Hz. Residual non-deuterated solvent was used as an internal standard. UV-Vis absorption spectra were recorded at room temperature on a Perkin Elmer Lambda 950 spectrometer or with a Shimadzu UV-1800. Matrix Assisted Laser Desorption/Ionization was performed on MALDI-TOF MS BIFLEX III Bruker Daltonics spectrometer using dithranol, DCTB or $\alpha$-terthiophene as matrix. Cyclic voltammetry was performed using a Biologic SP-150 potentiostat with positive feedback compensation in dichloromethane solutions purchased from Carlo Erba (HPLC grade). Tetrabutylammonium hexafluorophosphate $(0.1 \mathrm{M}$ as supporting electrolyte) was purchased from Sigma-Aldrich and recrystallized prior to use. Experiments were carried out under an inert atmosphere (Ar) using a glovebox, by scanning the negative potential first, in a one-compartment cell equipped with a platinum working microelectrode $(\varnothing=2 \mathrm{~mm})$ and a platinum wire as counter electrode. A silver wire immersed in $0.10 \mathrm{M} \mathrm{Bu}_{4} \mathrm{NPF}_{6} / \mathrm{CH}_{2} \mathrm{Cl}_{2}$ was used as pseudo-reference electrode and checked against the ferrocene/ferrocenium couple $\left(\mathrm{Fc} / \mathrm{Fc}^{+}\right)$before and after each experiment. Atomic-force microscopy (AFM) experiments were performed using the NanoObserver device from CS Instrument. The topographic images were obtained at room temperature in tapping mode. Images were processed with the Gwyddion free SPM data analysis software.

6-Azidohexyl-2-cyanoacetate and [6,6]-phenyl- $\mathrm{C}_{61}$ butyric acid propargyl ester $\mathrm{C}_{60}-\mathrm{A}$ were prepared according to the literature [18].

\section{Synthesis of Compounds}

TAT-Br (3-Bromo-5,10,15-trihexyl-10,15-dihydro-5H-diindolo[3,2-a:3',2'-c]carbazole): A solution of NBS (134 mg, $0.753 \mathrm{mmol})$ in DMF $(7 \mathrm{~mL}$ ) was added dropwise to a stirred mixture of TAT (500 $\mathrm{mg}$, $0.836 \mathrm{mmol})$ in $\mathrm{CHCl}_{3}(15 \mathrm{~mL})$ at $0{ }^{\circ} \mathrm{C}$. The resulting mixture was slowly warmed up to room temperature and stirred for an additional hour before being poured into water. The organic phase was extracted, dried over $\mathrm{Na}_{2} \mathrm{SO}_{4}$ and concentrated under vacuum. The crude product was purified by column chromatography on silica gel (eluent: Petroleum ether/Toluene 95/5 v/v) to afford TAT-Br (415 mg, $0.613 \mathrm{mmol}, 73.3 \%)$ as a white solid. ${ }^{1} \mathrm{H}$ NMR $\left(300 \mathrm{MHz}, \mathrm{CDCl}_{3}\right): \delta 8.26(\mathrm{~m}, 2 \mathrm{H}), 8.09(\mathrm{~d}, \mathrm{~J}=$ $8.6 \mathrm{~Hz}, 1 \mathrm{H}), 7.73(\mathrm{~d}, \mathrm{~J}=1.7 \mathrm{~Hz}, 1 \mathrm{H}), 7.63(\mathrm{dd}, \mathrm{J}=7.7,2.6 \mathrm{~Hz}, 2 \mathrm{H}), 7.52-7.29(\mathrm{~m}, 5 \mathrm{H}), 4.95-4.77(\mathrm{~m}$, $6 \mathrm{H}), 2.06-1.85(\mathrm{~m}, 6 \mathrm{H}), 1.27(\mathrm{~s}, 18 \mathrm{H}), 0.85-0.75(\mathrm{~m}, 9 \mathrm{H})$.

TAT-T (5,10,15-Trihexyl-3-(thiophen-2-yl)-10,15-dihydro-5H-diindolo[3,2-a:3',2'-c]carbazole ): TAT-Br (400 mg, $0.591 \mathrm{mmol})$ and $\mathrm{Pd}\left(\mathrm{PPh}_{3}\right)_{4}(41 \mathrm{mg}, 0.035 \mathrm{mmol})$ were combined in a dry Schlenk flask and purged several time by argon-vacuum cycles. Then, a freshly prepared tributyl(thiophen-2-yl)stannane $(276 \mathrm{mg}, 0.236 \mathrm{~mL}, 0.740 \mathrm{mmol})$ solution in degassed toluene $(40 \mathrm{~mL})$ was added and the reaction 
mixture was stirred at $80{ }^{\circ} \mathrm{C}$ overnight. Upon cooling to room temperature, water was added $(40 \mathrm{~mL})$ and the organic phase was separated. The aqueous phase was extracted with DCM. The combined organic phases were washed over brine, dried with $\mathrm{MgSO}_{4}$ and concentrated under vacuum. The crude was finally purified by column chromatography on silica gel (eluent: DCM/ PE 2/8 v/v) yielding TAT$\mathbf{T}$ as a pale yellow solid (140 mg, $0.206 \mathrm{mmol}, 34.8 \%) .{ }^{1} \mathrm{H}$ NMR $\left(300 \mathrm{MHz}, \mathrm{CDCl}_{3}\right): \delta 8.29(\mathrm{~d}, \mathrm{~J}=8.0$ $\mathrm{Hz}, 2 \mathrm{H}), 8.25(\mathrm{~d}, \mathrm{~J}=8.5 \mathrm{~Hz}, 1 \mathrm{H}), 7.83(\mathrm{bs}, 1 \mathrm{H}), 7.62(\mathrm{~m}, \mathrm{~J}=9.2 \mathrm{~Hz}, 2 \mathrm{H}+1 \mathrm{H}), 7.46(\mathrm{~m}, \mathrm{~J}=7.5 \mathrm{~Hz}, 2 \mathrm{H}$ $+1 \mathrm{H}), 7.39-7.30(\mathrm{~m}, 1 \mathrm{H}+2 \mathrm{H}), 7.17(\mathrm{dd}, \mathrm{J}=4.8,3.7 \mathrm{~Hz}, 1 \mathrm{H}), 4.99-4.86(\mathrm{~m}, 6 \mathrm{H}), 2.08-1.91(\mathrm{~m}$, $6 \mathrm{H}), 1.26(\mathrm{~s}, 18 \mathrm{H}), 0.87-0.77(\mathrm{~m}, 9 \mathrm{H})$.

${ }^{13} \mathrm{C}$ NMR $\left(76 \mathrm{MHz}, \mathrm{CDCl}_{3}\right): \delta 145.86,141.64,141.24,141.13,139.66,139.16,138.75,129.29,128.24$, $124.36,123.58,123.24,122.94,122.77,121.87,121.69,119.87,118.45,110.70,110.62,107.99,103.52$, 103.41, 103.35, 47.22, 47.12, 31.60, 31.57, 31.51, 29.95, 29.91, 29.82, 26.52, 26.50, 26.45, 22.62, 14.04.

TAT-CHO (5-(5,10,15-Trihexyl-10,15-dihydro-5H-diindolo[3,2-a:3',2'-c]carbazol-3-yl)thiophene-2carbaldehyde): A solution of $\mathrm{n}-\mathrm{BuLi} 1.6 \mathrm{M}$ in hexanes $(165 \mu \mathrm{L}, 0.265 \mathrm{mmol})$ was added dropwise at -78 ${ }^{\circ} \mathrm{C}$ to a stirred solution of TAT-T $(120 \mathrm{mg}, 0.176 \mathrm{mmol})$ solubilized in $15 \mathrm{~mL}$ of dried THF. The mixture was stirred for $30 \mathrm{~min}$ at this temperature before adding DMF ( $26 \mathrm{mg}, 27 \mu \mathrm{L}, 0.353 \mathrm{mmol})$. The resulting mixture was stirred and allowed to warm up to room temperature overnight. The reaction was quenched with water, extracted with DCM, washed with brine, dried over $\mathrm{MgSO}_{4}$ and concentrated under vacuum. The crude product was purified by column chromatography on silica gel (eluent: DCM) affording TAT-CHO $(80 \mathrm{mg}, 0.113 \mathrm{mmol}, 64 \%)$ as an orange solid. ${ }^{1} \mathrm{H}$ NMR $\left(300 \mathrm{MHz}, \mathrm{CDCl}_{3}\right): \delta$ $9.89(\mathrm{~s}, 1 \mathrm{H}), 8.23(\mathrm{~d}, J=8.1 \mathrm{~Hz}, 1 \mathrm{H}), 8.19(\mathrm{~d}, J=8.2 \mathrm{~Hz}, 1 \mathrm{H}), 8.06(\mathrm{~d}, \mathrm{~J}=8.5 \mathrm{~Hz}, 1 \mathrm{H}), 7.72(\mathrm{~d}, \mathrm{~J}=4.0$ $\mathrm{Hz}, 1 \mathrm{H}), 7.70(\mathrm{~d}, \mathrm{~J}=1.4 \mathrm{~Hz}, 1 \mathrm{H}), 7.58(\mathrm{t}, \mathrm{J}=8.2 \mathrm{~Hz}, 2 \mathrm{H}), 7.52-7.43(\mathrm{~m}, 1 \mathrm{H}+2 \mathrm{H}), 7.42(\mathrm{~d}, \mathrm{~J}=4.0 \mathrm{~Hz}$, $1 \mathrm{H}), 7.34(\mathrm{t}, \mathrm{J}=7.5 \mathrm{~Hz}, 2 \mathrm{H}), 4.87-4.63(\mathrm{~m}, 6 \mathrm{H}), 1.96(\mathrm{~d}, \mathrm{~J}=19.4 \mathrm{~Hz}, 6 \mathrm{H}), 1.38-1.13(\mathrm{~m}, 18 \mathrm{H}), 0.89-$ $0.78(\mathrm{~m}, 9 \mathrm{H})$.

TAT- $\boldsymbol{\sigma}-\mathbf{N}_{3}$ : To a stirred solution of TAT-CHO $(80 \mathrm{mg}, 0.113 \mathrm{mmol})$ and 6-Azidohexyl-2-cyanoacetate (36 mg, $0.170 \mathrm{mmol})$ in $\mathrm{CHCl}_{3}(15 \mathrm{~mL})$ were added $2-3$ drops of $\mathrm{Et}_{3} \mathrm{~N}$. The reaction mixture was refluxed under argon for 3 days. Then, the solvent was removed under vacuum and the residue was purified by column chromatography on silica gel (eluent: DCM) affording TAT- $\boldsymbol{\sigma}-\mathbf{N}_{\mathbf{3}}$ as a red solid (98 mg, $0.109 \mathrm{mmol}, 96.3 \%) .{ }^{1} \mathrm{H}$ NMR $\left(300 \mathrm{MHz}, \mathrm{CDCl}_{3}\right): \delta 8.33-8.30(\mathrm{~m}, 1 \mathrm{H}), 8.30-8.21(\mathrm{~m}, 3 \mathrm{H}), 7.86$ $(\mathrm{d}, \mathrm{J}=1.2 \mathrm{~Hz}, 1 \mathrm{H}), 7.80(\mathrm{~d}, \mathrm{~J}=4.1 \mathrm{~Hz}, 1 \mathrm{H}), 7.67-7.60(\mathrm{~m}, 3 \mathrm{H}), 7.54(\mathrm{~d}, \mathrm{~J}=4.0 \mathrm{~Hz}, 1 \mathrm{H}), 7.51-7.43$ $(\mathrm{m}, 2 \mathrm{H}), 7.40-7.31(\mathrm{~m}, 2 \mathrm{H}), 5.00-4.81(\mathrm{~m}, 6 \mathrm{H}), 4.32(\mathrm{t}, \mathrm{J}=6.6 \mathrm{~Hz}, 2 \mathrm{H}), 3.31(\mathrm{t}, \mathrm{J}=6.8 \mathrm{~Hz}, 2 \mathrm{H}), 1.99$ $(\mathrm{s}, 6 \mathrm{H}), 1.87-1.74(\mathrm{~m}, 2 \mathrm{H}), 1.72-1.60(\mathrm{~m}, 2 \mathrm{H}), 1.52-1.40(\mathrm{~m}, 4 \mathrm{H}), 1.34-1.16(\mathrm{~m}, 18 \mathrm{H}), 0.84-0.75$ $(\mathrm{m}, 9 \mathrm{H}) .{ }^{13} \mathrm{C}$ NMR $\left(76 \mathrm{MHz}, \mathrm{CDCl}_{3}\right): \delta 163.50,156.77,146.80,141.33,141.12,141.01,140.28,139.74$, 139.60, 138.58, 134.33, 127.07, 125.01, 123.91, 123.37, 123.13, 121.97, 121.71, 121.69, 120.09, 120.00, 118.73, 116.47, 110.76, 110.70, 108.27, 103.67, 103.29, 103.28, 96.79, 66.32, 51.49, 47.21, 31.59, 31.55, $31.45,29.95,29.83,28.90,28.60,26.52,26.36,25.64,22.62,22.53,14.10,14.06,14.03$. HRMS (FAB): calculated for $\mathrm{C}_{56} \mathrm{H}_{65} \mathrm{~N}_{7} \mathrm{O}_{2} \mathrm{~S}: 899.49$, found: 899.4908

TAT- $\sigma-\mathbf{C}_{60}$ : Five drops of $N, N, N^{\prime}, N^{\prime \prime}, N^{\prime \prime}$-pentamethyldiethylenetriamine (PMDETA) dispersed in HPLC grade toluene $(50 \mathrm{~mL})$ were degassed three times via the "freeze, pump and thaw" technic. This solution was transferred using a cannula into a schlenk flask containing $\mathbf{C}_{60}-\mathbf{A}$ (68 $\left.\mathrm{mg}, 0.073 \mathrm{mmol}\right)$, $\mathrm{CuBr}(5 \mathrm{mg})$ and TAT- $\sigma-\mathbf{N}_{\mathbf{3}}(60 \mathrm{mg}, 0.067 \mathrm{mmol})$ under an argon atmosphere. The reaction mixture was protected from light and stirred for one night. The solvent was then removed under vacuum and the residue was purified by chromatography on silica gel using a mixture of dichloromethane and ethyl acetate as eluent (from 100:0 v/v to $90: 10 \mathrm{v} / \mathrm{v}$ ). The resulting solid was further purified by dissolution in dichloromethane and subsequent precipitation with pentane to afford the pure expected TAT- $\sigma-\mathbf{C}_{60}(93$ $\mathrm{mg}, 0.051 \mathrm{mmol}, 76 \%$ ) as a brown red powder. ${ }^{1} \mathrm{H}$ NMR $\left(499 \mathrm{MHz}, \mathrm{CDCl}_{3}\right): \delta 8.33(\mathrm{~s}, 1 \mathrm{H}), 8.29-8.22$ $(\mathrm{m}, 3 \mathrm{H}), 7.87(\mathrm{~d}, \mathrm{~J}=6.9 \mathrm{~Hz}, 3 \mathrm{H}), 7.81(\mathrm{~d}, \mathrm{~J}=3.8 \mathrm{~Hz}, 1 \mathrm{H}), 7.68-7.60(\mathrm{~m}, 4 \mathrm{H}), 7.57-7.42(\mathrm{~m}, 6 \mathrm{H})$, $7.39-7.33(\mathrm{~m}, 2 \mathrm{H}), 5.24(\mathrm{~s}, 2 \mathrm{H}), 5.01-4.84(\mathrm{~m}, 6 \mathrm{H}), 4.38(\mathrm{t}, \mathrm{J}=7.2 \mathrm{~Hz}, 2 \mathrm{H}), 4.31(\mathrm{t}, \mathrm{J}=6.3 \mathrm{~Hz}, 2 \mathrm{H})$, $2.91-2.80(\mathrm{~m}, 2 \mathrm{H}), 2.56(\mathrm{~s}, 2 \mathrm{H}), 2.24-2.12(\mathrm{~m}, 2 \mathrm{H}), 2.06-1.89(\mathrm{~m}, 8 \mathrm{H}), 1.82-1.72(\mathrm{~m}, 2 \mathrm{H})$, $1.54-1.47(\mathrm{~m}, 2 \mathrm{H}), 1.47-1.38(\mathrm{~m}, 2 \mathrm{H}), 1.37-1.31(\mathrm{~m}, 4 \mathrm{H}), 1.30-1.15(\mathrm{~m}, 14 \mathrm{H}), 0.82(\mathrm{t}, \mathrm{J}=6.6 \mathrm{~Hz}$, $6 \mathrm{H}), 0.77(\mathrm{t}, \mathrm{J}=7.0 \mathrm{~Hz}, 3 \mathrm{H}) .{ }^{13} \mathrm{C} \mathrm{NMR}\left(126 \mathrm{MHz} \mathrm{CDCl}_{3}\right): \delta 173.08,163.45,156.95,148.85,147.83$, $146.89,145.88,145.24,145.20,145.18,145.11,145.08,144.83,144.78,144.73,144.69,144.54,144.46$, $144.07,143.81,143.77,143.16,143.06,143.02,142.95,142.25,142.22,142.16,142.12,141.41,141.15$, $141.04,140.80,140.37,139.90,139.65,138.64,138.09,137.63,136.85,134.37,132.22,128.57,128.37$, $127.07,125.15,123.99,123.82,123.44,123.17,122.06,121.75,120.13,120.05,118.82,116.53,110.75$, 
108.36, 103.81, 103.40, 96.72, 79.92, 66.22, 57.97, 51.88, 50.38, 47.25, 34.05, 33.75, 31.61, 31.58, 31.47, 30.28, 30.00, 29.86, 28.41, 26.55, 26.51, 26.40, 26.21, 25.60, 22.63, 22.55, 22.36, 14.11, 14.07, 14.04. HRMS (FAB): calculated for $\mathrm{C}_{130} \mathrm{H}_{79} \mathrm{~N}_{7} \mathrm{O}_{4} \mathrm{~S}: 1833.59$, found: 1833.5903

Device fabrication and testing: Pre-patterned indium-tin oxide coated glass slides of $24 \times 25 \times 1.1 \mathrm{~mm}^{3}$ with a sheet resistance of $\mathrm{RS}=7 \Omega$ /sq were purchased from Visiontek Systems. The substrates were washed by successive ultrasonic baths, namely diluted Deconex ${ }^{\circledR} 12$ PA-x solution ( $2 \%$ in water), acetone and isopropanol for $15 \mathrm{~min}$ each. Once dried under a stream of air, UV-ozone plasma treatment (Ossila UV/Ozone cleaner E511) was performed for $15 \mathrm{~min}$. A filtered aqueous solution of poly(3,4ethylenedioxy-thiophene)-poly(styrenesulfonate) (PEDOT:PSS; Ossila Al 4083) through a $0.45 \mu \mathrm{m}$ RC membrane (Minisart ${ }^{\circledR}$ RC 15) was spun-cast onto the ITO surface at $5000 \mathrm{rpm}$ for $40 \mathrm{~s}$ before being baked at $120{ }^{\circ} \mathrm{C}$ for $30 \mathrm{~min}$. The dyad TAT- $\sigma-\mathbf{C}_{60}$ was then spun-cast and devices were completed by the thermal deposition of aluminum $(100 \mathrm{~nm})$ at a pressure of $1.5 \times 10^{-5}$ Torr through a shadow mask defining six cells of $27 \mathrm{~mm}^{2}$ each $(13.5 \mathrm{~mm} \times 2 \mathrm{~mm}) . \mathrm{J}-\mathrm{V}$ curves were recorded in the dark and under illumination using a Keithley 236 source-measure unit and a home-made acquisition program. The light source is an AM1.5 Solar Constant 575 PV simulator (Steuernagel Lichttecknik, equipped with a metal halogen lamp, $100 \mathrm{~mW} \cdot \mathrm{cm}^{-2}$ ). The light intensity was measured by a broad-band power meter (13PEM001, Melles Griot). EQE were performed under ambient atmosphere using a halogen lamp (Osram) with an Action Spectra Pro 150 monochromator, a lock-in amplifier (Perkin-Elmer 7225) and a S2281 photodiode (Hamamatsu).

\section{Conflict of Interests}

The authors declare there are no conflicts of interests.

\section{Acknowledgements}

The Région Pays de la Loire and the RFI LUMOMAT are thanked for the PhD grant of A. L. and the funding of the SAMOA project (Etoile Montante 2017). Authors thank the MATRIX SFR of the University of Angers and more precisely the ASTRAL and CARMA platforms for the characterization of organic compounds and device preparation/characterization respectively. G. L. thanks the European Union's Horizon 2020 research and innovation program under Marie Sklodowska Curie Grant agreement No.722651 (SEPOMO). The work in the Laboratory for Chemistry of Novel Materials was supported by the Consortium des Équipements de Calcul Intensif (CÉCI), funded by the Fonds de la Recherche Scientifiques de Belgique (F.R.S.- FNRS) under Grant No. 2.5020.11, as well as the Tier-1 supercomputer of the Fédération Wallonie-Bruxelles, infrastructure funded by the Walloon Region under Grant Agreement No. 1117545. D.B. is a FNRS Research Director .G. C. W. and S. V. D thank the University of Calgary and the Canadian Foundation for Innovation for salary and solar cell equipment support, respectively.

\section{References}

[1] Meng, L., Zhang, Y.; Wan, X., Li, C., Zhang, X., Wang, Y., Ke, X., Xiao, Z., Ding, L., Xia, R., Yip, H.-L., Cao, Y., Chen, Y., Science, 2018, 1094-1098.

[2] Che X., Li, Y., Qu Y., Forrest, S. R., Nature Energy, 2018, 3, 422-427.

[3] Zhao, W., Li, S., Yao, H., Zhang, S., Zhang, Y., Yang B., Hou, J., J, Am. Chem. Soc., 2017, 139, 7148-7151.

[4] Antohe, S., Iftimie, S., Hrostea, L., Antohe V. A., Girtan, M., Thin Solid Films, 2017, 642, 219-231.

[5] Beaujuge P. M., Fréchet, J. M. J., J. Am. Chem. Soc., 2011, 133, 20009-20029.

[6] Warnan, J., El Labban, A., Cabanetos, C., Hoke, E. T., Shukla, P. K., Risko, C., Brédas, J.-L., McGehee M. D., Beaujuge, P. M., Chem. Mater., 2014, 26, 2299-2306. 
[7]

[8]

[9]

Graham, K. R., Cabanetos, C., Jahnke, J. P., Idso, M. N., El Labban, A., Ngongang Ndjawa, G. O., Heumueller, T., Vandewal, K., Salleo, A., Chmelka, B. F., Amassian, A., Beaujuge P. M., McGehee, M. D., , J. Am. Chem. Soc., 2014, 136, 9608-9618.

Dang, M. T., Wantz, G., Bejbouji, H., Urien, M., Dautel, O. J., Vignau L., Hirsch, L., Solar Energy Materials and Solar Cells, 2011, 95, 3408-3418.

Dang, M. T., Hirsch, L., Wantz G., Wuest J. D., Chem. Rev., 2013, 113, 3734-3765.

Segura, J. L., N. Martín, N., Guldi, D. M., Chem. Soc. Rev., 2005, 34, 31-47.

Nierengarten, J.-F., Eckert, J.-F., Nicoud, J.-F., Ouali, L., Krasnikov V., Hadziioannou, G., Chem. Commun., 1999, 7, 617-618.

Roncali, J., Adv. Energy Mater., 2011, 1, 147-160.

Chen, T. L., Zhang, Y., Smith, P., Tamayo, A., Liu Y., Ma, B., ACS Appl. Mater. Inter., 2011, 3, 2275-2280.

Na] Narayanaswamy, K., Venkateswararao, A., Nagarjuna, P., Bishnoi, S., Gupta, V., Chand, S., Singh, S. P., Angew. Chem. Int. Ed., 2016, 55, 12334-12337.

5] Nguyen, T. L., Lee, T. H., Gautam, B., Park, S. Y., Gundogdu, K., Kim J. Y., Woo, H. Y., Adv. Func. Mater., 2017, 27, 1702474.

Nishizawa, T., Lim, H. K., Tajima K., Hashimoto, K., Chem. Commun., 2009, 18, 2469-2471.

Izawa, S., Hashimoto, K., Tajima, K., Phys. Chem. Chem. Phys., 2012, 14, 16138-16142.

Labrunie A., Gorenflot J., Babics M., Alévêque O., Dabos-Seignon S., Balawi A. H., Kan Z., Wohlfahrt M., Levillain E., Hudhomme P., Beaujuge P. M., Laquai F., Cabanetos C., Blanchard P., Chem. Mater., 2018, 30, 3474-3485.

] Bura, T., Leclerc, N., Bechara, R., Lévêque, P., Heiser T., Ziessel, R., Adv. Energy Mater., 2013, 3, 1118-1124.

Bura, T., Leclerc, N., Fall, S., Lévêque, P., Heiser T., Ziessel, R., Org. Lett., 2011, 13, 6030-6033.

Bul But, I., Lévêque, P., Heinrich, B., Heiser, T., Bechara, R., Zimmermann, N., Méry, S., Ziessel, R., Leclerc, N., J. Mater. Chem. A, 2015, 3, 6620-6628.

Cardona, C. M., Li, W., Kaifer, A. E., Stockdale D., Bazan, G. C., Adv. Mater., 2011, 23, 2367-2371.

Frisch, M. J., Trucks, G. W., Schlegel, H. B., Scuseria, G. E., Robb, M. A., Cheeseman, J. R., Scalmani, G., Barone, V., Petersson, G. A., Nakatsuji, H., Li, X., Caricato, M., Marenich, A. V., Bloino, J., Janesko, B. G., Gomperts, R., Mennucci, B., Hratchian, H. P., Ortiz, J. V., Izmaylov, A. F., Sonnenberg, J. L., Williams-Young, D., , Ding, F., Lipparini, F., Egidi, F., Goings, J., Peng, B., Petrone, A., Henderson, T., Ranasinghe, D., Zakrzewski, V. G., Gao, J., Rega, N., Zheng, G., Liang, W., Hada, M., Ehara, M., Toyota, K., Fukuda, R., Hasegawa, J., Ishida, M., Nakajima, T., Honda, Y., Kitao, O., Nakai, H., Vreven, T., Throssell, K., Montgomery Jr., J. A., Peralta, J. E., Ogliaro, F., Bearpark, M. J., Heyd, J. J., Brothers, E. N., Kudin, K. N., Staroverov, V. N., Keith, T. A., Kobayashi, R., Normand, J., Raghavachari, K., Rendell,A. P., Burant, J. C., Iyengar, S. S., Tomasi, J., Cossi, M., Millam, J. M., Klene, M., Adamo, C., Cammi, R., Ochterski, J. W., Martin, R. L., Morokuma, K., Farkas, O., Foresman J. B., Fox, D. J., Gaussian 16 Rev. B.01. 2016, Wallingford, CT.

Received: 30 August 2018

Accepted: 17 October 2018

Published online: 31 October 2018

ORCID ID for authors

Clément Cabanetos: 0000-0003-3781-887X

Phillippe Blanchard: 0000-0002-9408-8108

Gregory Welch: 0000-0002-3768-937X

Giacomo Londi: 0000-0001-7777-9161

Sergey Dayneko: 0000-0002-0604-6099

Sylvie Dabos-Seignon: 0000-0002-7900-6354 
(c) () () This article is licensed under a Creative Commons Attribution-NonCommercial 4.0 International License, cc) which permits use, sharing, adaptation, distribution and reproduction in any medium or format, as long as it is non-commercial, you give appropriate credit to the original author(s) and the source, provide a link to the Creative Commons license, and indicate if changes were made. The images or other third-party material in this article are included in the article's Creative Commons license, unless indicated otherwise in a credit line to the material. If material is not included in the article's Creative Commons license and your intended use is not permitted by statutory regulation or exceeds the permitted use, you will need to obtain permission directly from the copyright holder. To view a copy of this license, visit http://creativecommons.org/licenses/by/4.0/. 